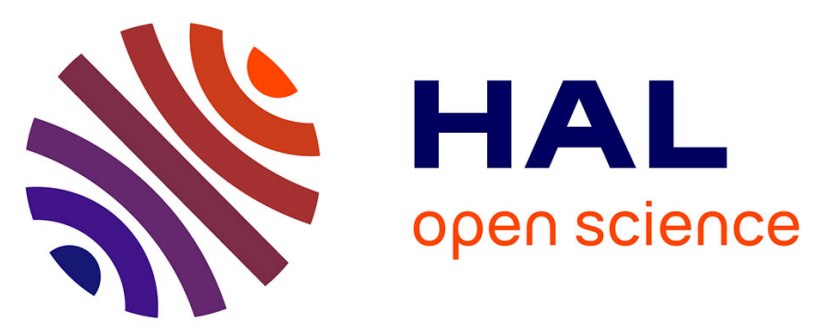

\title{
European eel (Anguilla anguilla): prediction of spawner escapement from continental population parameters
}

\author{
Eric Feunteun, Anthony Acou, Pascal Laffaille, Antoine Legault
}

\section{To cite this version:}

Eric Feunteun, Anthony Acou, Pascal Laffaille, Antoine Legault. European eel (Anguilla anguilla): prediction of spawner escapement from continental population parameters. Canadian Journal of Fisheries and Aquatic Sciences, 2000, vol. 57, 10.1139/f00-096 . hal-00735979

\section{HAL Id: hal-00735979 \\ https://hal.science/hal-00735979}

Submitted on 27 Sep 2012

HAL is a multi-disciplinary open access archive for the deposit and dissemination of scientific research documents, whether they are published or not. The documents may come from teaching and research institutions in France or abroad, or from public or private research centers.
L'archive ouverte pluridisciplinaire HAL, est destinée au dépôt et à la diffusion de documents scientifiques de niveau recherche, publiés ou non, émanant des établissements d'enseignement et de recherche français ou étrangers, des laboratoires publics ou privés. 


\title{
European eel (Anguilla anguilla): prediction of spawner escapement from continental population parameters
}

\author{
Eric Feunteun, Anthony Acou, Pascal Laffaille, and Antoine Legault
}

\begin{abstract}
This paper describes the assessment of silver European eel (Anguilla anguilla) escapement based on a "sedentary" population fraction analysis in a $60-\mathrm{km}^{2}$ watershed of northern Brittany (France). Downstream migration fluxes were monitored using eel traps and related to environmental factors. Intensive electrofishing and fyke-net fishing were conducted to assess eel biomass, densities, and population structure. A total of 564 eels, including 81 silver eels, were PIT tagged. In 1996, 616 eels were caught in the catchment including 68 silver eels (11\%). During the following downstream migration period, 12 of the PIT-tagged silver eels, among a total of 678, were recaptured in the downstream traps. Seven were recaptured in the catchment in 1997. It was shown that (i) only about $20 \%$ of the silver eels present in the catchment emigrated during the following year, (ii) $12 \%$ stayed in the catchment including two (3.4\%) that recovered yellow eel characteristics, and (iii) the other eels either died or settled in the catchment but were not recaptured. It was also estimated that $2 \%$ (650 eels) of the population (34 000 eels) among 3000 silver eels considered "emigration candidates" emigrated each year,.
\end{abstract}

Résumé : Le but de cette note est de proposer une approche permettant d'estimer l'échappement des anguilles européenne argentées (Anguilla anguilla) basée sur une analyse de la fraction de la population sédentaire dans un bassin versant de $60 \mathrm{~km}^{2}$ de l'ouest de la France. Les flux de migration catadrome ont été observés en utilisant des pièges à anguilles et ont été mis en relation avec les facteurs environnementaux. Des campagnes de pêche électrique et de verveux ont permis d'estimer les biomasses, densités et structures de la population d'anguilles. Cinq cents soixante-quatre anguilles, incluant 81 anguilles argentés, ont été marquées par PIT tag. En 1996, 616 anguilles comprenant 68 argentées ont été capturées dans le bassin versant. Lors du pic de migration, parmi les 678 argentées capturées dans le piège de dévalaison, 12 anguilles argentées marquées ont été recapturées. Sept anguilles argentées ont été recapturées dans le bassin versant en 1997. Ces résultats montrent que $(i)$ seulement $20 \%$ des anguilles argentées présentes dans le bassin versant migrent dans l'année, (ii) 12\% restent dans le bassin versant, dont 2 (3.4\%) qui régressent au stade jaune et (iii) les autres anguilles meurent où se sédentarisent dans le bassin versant. Le stock total d'anguille du bassin versant est de 34000 anguilles, parmi celles-ci, on estime à environ 3000 individus le stock d'anguilles argentées considérées comme « candidates à l'émigration ». Mais seules 650 anguilles argentées dévalent réellement, soit environ 2\% du stock.

\section{Introduction}

Since the 1980s, the European eel (Anguilla anguilla) stock has declined throughout its distribution range, including all accessible continental and coastal hydrosystems that link with the Baltic Sea, the North Sea, the Channel, and the

E. Feunteun ${ }^{1}$ and P. Laffaille. Université de Rennes I, UMR 6553 "Ecobio," Laboratoire d'Evolution des Systèmes Naturels et Modifiés, avenue du Général Leclerc, 35042 Rennes Cedex, France.

A. Acou. Université de Rennes I, UMR 6553 "Ecobio," Laboratoire d'Evolution des Systèmes Naturels et Modifiés, avenue du Général Leclerc, 35042 Rennes Cedex, France, and Fish-Pass, 91 rue de Saint-Brieuc, 35000 Rennes, France.

A. Legault. Fish-Pass, 91 rue de Saint-Brieuc, 35000 Rennes, France.

${ }^{1}$ Author to whom all correspondence should be addressed. e-mail: eric.feunteun@univ-rennes1.fr
Atlantic and Mediterranean coasts between Iceland and Morocco (Moriarty and Dekker 1997). The eel is one of the major components of many estuarine and fluvial aquatic systems. It has an important commercial value throughout Europe (about Euro 180 million $\cdot$ year $^{-1}$ ), and its biological cycle is long (5-18 years) and remains insufficiently known to develop reliable sustainable management policies.

The European eel dominates fish communities of many inland aquatic systems. For instance, it represents more than $50 \%$ of the fish biomass in estuarine systems such as lagoons (Feunteun 1994; Feunteun and Marion 1994) and in rivers of the Mediterranean or Atlantic coast, at least in their downstream reaches (Chancerel 1994; Feunteun et al. 1998). The species is found in practically every type of adequate habitat, and it is quite often the only species that occurs in shallow waters unsuitable for any other species.

All species of eels (Anguilla spp.) are highly migratory amphihaline species. Since Schmidt's (1922) work, spawning in European eel is thought to take place somewhere in the Sargasso Sea. At their arrival on the continental shelf, leptocephali larvae metamorphose into glass eels, which 
start colonising continental waters. The growth stage lasts $3-$ 8 years in males and 5-15 years in females. After this growth stage, yellow eels lose their yellow pigments, their back becomes dark brown or black and their belly becomes white, the eye volume increases, and the pectoral fins grow longer. All these changes are characteristic of a second metamorphosis into silver eels adapted to live in deep marine waters. After a few months, silver eels start their downstream migration towards marine waters and eventually return to the spawning grounds in the Sargasso Sea. Silver eels leaving continental waters are considered to be maturing fish, gonad maturation occurring in oceanic waters (Fontaine 1994).

Therefore, little is known about what happens between maturing silver eel stages and subsequent return of glass eels to the Northeast Atlantic and Mediterranean coasts. This lack of knowledge is at the origin of a controversy about the existence of a stock-recruitment relationship (Gascuel and Fontenelle 1994). ICES (1998) considers that the species is outside safe biological limits, and therefore, application of the precautionary principal is necessary. In particular, the ICES/EIFAC working group on eels recommended the enhancement of escapement for glass eels, yellow eels, and silver eels and the fixing of standard escapement objectives at the international level (ICES 1998).

This recommendation is weakened by the fact that the status of the stock is poorly assessed by a number of national or regional surveys of fluvial recruitment and that nothing is known about the minimal number of glass eels needed to sustain sufficient eel population and subsequent silver eel emigration (Feunteun and Vigneux 1998). Even weaker is the knowledge about silver eel escapement and related fisheries. Monitoring methods already exist and have been used for glass eels in a range of systems throughout Europe (e.g., Gascuel et al. 1994; Legault 1994; Moriarty and Dekker 1997), but no such approach has been conducted for silver eels.

The aim of our paper is to propose an approach to assess, at the scale of a whole river system, relationships between silver eel migration dynamics, structure of the "sedentary fraction" of eel populations, and environmental factors.

\section{Material and methods}

\section{Study site}

The Frémur (Fig. 1) is a small river of northern Brittany (France) that opens into the British Channel next to Saint Malo. Its catchment covers about $60 \mathrm{~km}^{2}$, and the overall length of the river and its tributaries is $45 \mathrm{~km}$, comprising $17 \mathrm{~km}$ for the main stream. The slope varies between 0.1 and $2 \%$ with an average of $0.6 \%$. Despite its small size, the Frémur provides for a wide range of habitats from high-velocity streams of the trout zone to lentic waters of the bream zone in downstream areas, human-made ponds and reservoirs, wetlands, etc. The total extent of water is 75 ha including 5 ha of running waters (streams) and 70 ha of still waters (ponds and reservoirs). Therefore, this river appears to be representative of small coastal catchments of western France.

A total of six dams and weirs are present on the catchment. Three of them were totally impassable until they were equipped with eel passes (Feunteun et al. 1998). The most important one, Bois Joli, was built in 1991. It is $14 \mathrm{~m}$ high and creates a $3 \times$ $10^{6} \mathrm{~m}^{3}$ reservoir to provide the county with drinking water. Most of the time, it is not full and the flow is controlled by pipes. When it is full, the water flows over a discharge weir. It has been equipped with an eel lift to restore upstream migration, but no equipment has been provided for downstream migration (Fig. 1).

\section{Sedentary stock assessment}

Electrofishing was conducted in $30-\mathrm{m}$-long stream sections delimited by 3-mm-mesh stop nets. A "heron" (Lamarque et al. 1978) apparatus was used. It delivered direct current (150-365 V and 0.8-6 A). According to the width and the depth of river sections, fishing was conducted either wading in the water or from a boat $(0.09 \%$ of the stations). A standardised depletion method (Feunteun 1994; Lambert et al. 1994; Feunteun et al. 1998) was used to assess fish abundance (number and grams per square metre) using a Carle and Strub (1978) estimator. In September 1996, a total of 34 river sections were sampled between the estuary and streams located $15 \mathrm{~km}$ upstream, covering $2.4 \%$ of the available river length. In September 1997, 32 stations were sampled, covering a total of $2.1 \%$ of the river length. In the deepest habitats (ponds and reservoirs), we also used unbaited fyke nets (3-mm mesh). Fyke-net results were used to describe the population structure but were not used for stock assessment. A total of five sites were sampled with fyke nets in 1996 and six in 1997, all located in the Bois Joli reservoir. In spring 1997, a limited campaign using electricity was conducted to test marking efficiency and also permitted the recapture of a few fish marked in 1996.

Eels were measured (length and weight) and released directly outside the sampled river section immediately after their capture. Silver eels were identified using three criteria: colour of the back and belly, presence of a well-marked lateral line, and eye diameter according to Pankhurst (1982). If one of the three criteria (most often colour) did not occur, the eel was identified as yellow/silver. If only one (generally eye diameter) or none occurred, the eel was noted as yellow. Considering the shallowness of the stream, catchability was very high (on average, $70 \%$ of the standing stock was caught at the first removal). Therefore, the efficiency of the method appeared to be very good for eel sampling (including large eels), as has been stressed in previous studies (e.g., Feunteun 1994; Lambert et al. 1994; Feunteun et al. 1998).

\section{PIT tags}

All eels $>200 \mathrm{~mm}$, including silver eels, were marked individually using PIT tags (Prentice et al. 1990). The PIT tags were injected with a syringe into the general cavity. Induced mortality and PIT tag rejection were tested according to Prentice et al. (1990), Haines and Modde (1996), and Baisez (1997). Fourteen percent of the tags were rejected within an hour after the injection (Parker 1995; Baisez 1997). After this period, tag losses were very low. Therefore, the eels were kept for at least an hour after tagging before they were released in the river.

\section{Downstream migration dynamics}

A trap was installed on the Pont es Omnès dam; it was designed to capture every descending eel $>200 \mathrm{~mm}$ under practically every flow condition. Daily monitoring was conducted between September 1996 and June 1998 in order to count the number of descending eels. Each fish was measured, weighed, and the presence of PIT tags detected using a magnetic detector. Environmental parameters (temperature, flow, rainfall, etc.) were measured.

A total of 19 escapement tests were regularly conducted by releasing eel batches (19-57 fish) at the top of the downstream trap of Pont es Omnès. The escapements were about $0 \%$ except during a very short period (5 days) when the river flow exceeded $1500 \mathrm{~L} \cdot \mathrm{s}^{-1}$. The water overflowed the collecting gutter, permitting eels to escape. Then the average escapement amounted to $37 \%$ (9$67 \%$ ). The daily eel catches were corrected for the daily escapement rates. 
Fig. 1. Location and characteristics of the Frémur's catchment. Open arrows represent batches of two or three river sections sampled by electrofishing. Circls represent the locations of fyke-net fishing. Bars indicate the locations of major dams. A, Pont Avet reservoir ( $2 \mathrm{~km}$ from the river mouth); B, Pont es Omnès reservoir (4.5 km from the sea); C, Bois Joli reservoir (6 km from the sea); I, silver eel trap; II, Bois Joli dam.

\section{Channel}

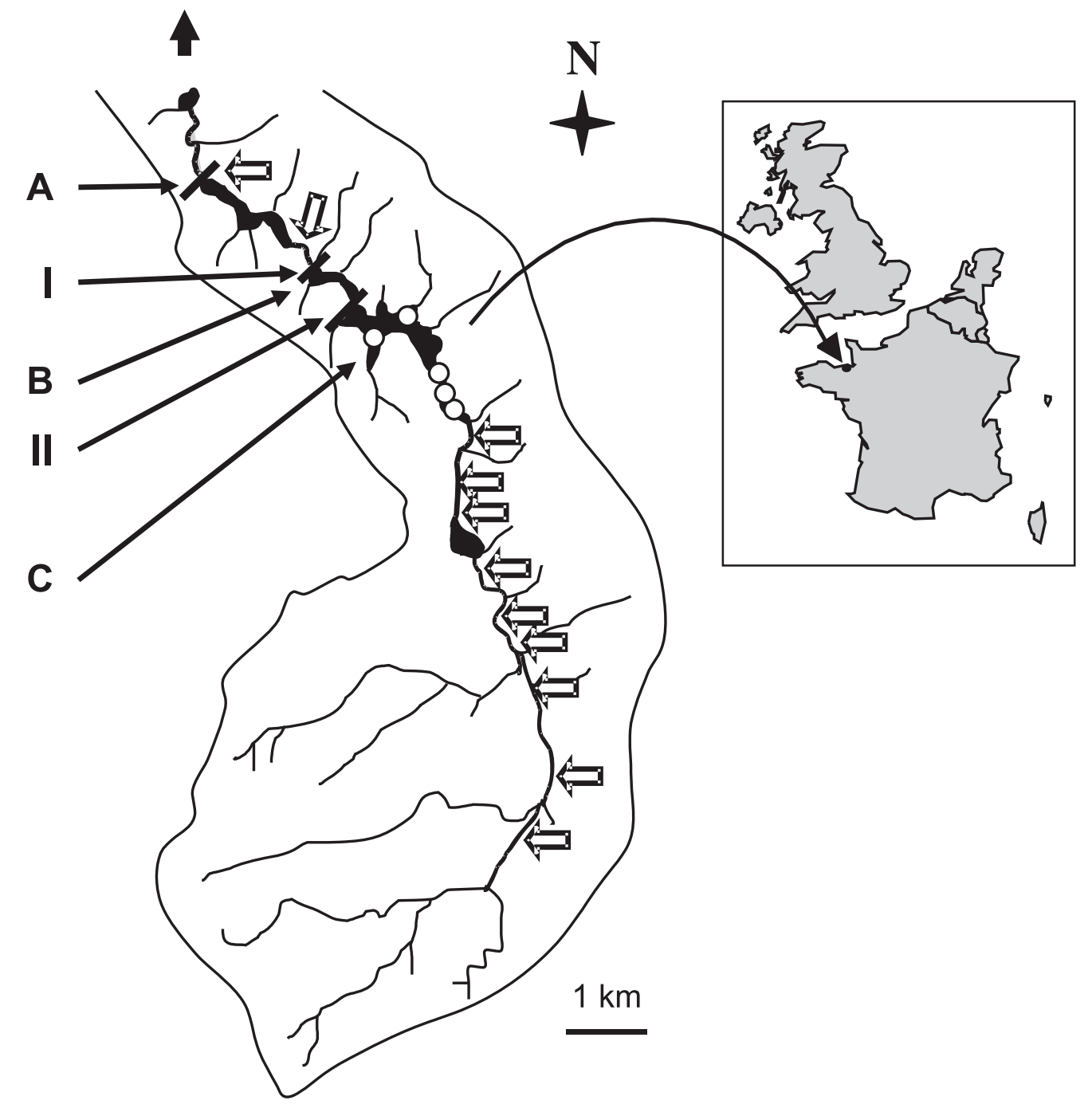

\section{Population size estimates}

Population size was estimated by two means: extrapolation from Carle and Strub (1978) estimates and the mark-recapture method. The average density and biomass estimated in sampled river sections by electrofishing were extrapolated to the whole stream surface using the Carle and Strub (1978) estimation. The size of the silver eel stock in the basin was calculated from the size of the total silver eel run (trap data) and the fraction of the tagged population recaptured in the run (recapture data) using

$$
S=N_{\mathrm{se}} \times n_{\mathrm{se}} / m
$$

where $S$ is the size of the silver eel stock, $N_{\text {se }}$ is the number of silver eels tagged, $n_{\mathrm{se}}$ is the number of silver eels caught in the trap, and $m$ is the number of marked silver eels recaptured in the trap.

\section{Results}

\section{Sedentary fraction of the population}

The population comprised eels between 60 and $780 \mathrm{~mm}$ (Fig. 2). In both years, a low proportion of elvers (young recently pigmented eels) was observed, confirming the low recruitment of glass eels due to physical obstruction of the river by major dams (Feunteun et al. 1998). In 1996, the strength of the 300 - to $420-\mathrm{mm}$ size-class seemed to be higher than in 1997 with, respectively, $40 \%$ and only $25 \%$ of the sample. Silver and yellow/silver eel population structure is dominated by the 300 - to $420-\mathrm{mm}$ size-class, which represents $89 \%$ of this category in both years. This size-class is dominated by males (Tesch 1977; Rossi and Colombo 1979; Adam 1997). The proportion of males was $88.9 \%$ in 1996 
Fig. 2. Length histogram of eels sampled in the Frémur catchment in (a) September 1996 and (b) September 1997. Open bars, yellow eels $(N=531$ in 1996 and $N=538$ in 1997); solid bars, silver eels $(N=68$ in 1996 and $N=47$ in 1997); hatched bars, yellow/silver eels $(N=17$ in 1996 and $N=24$ in 1997).

(a)

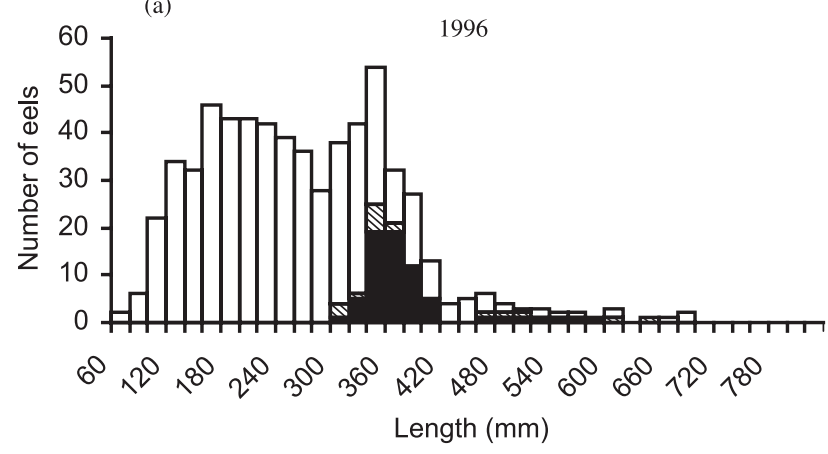

(b)

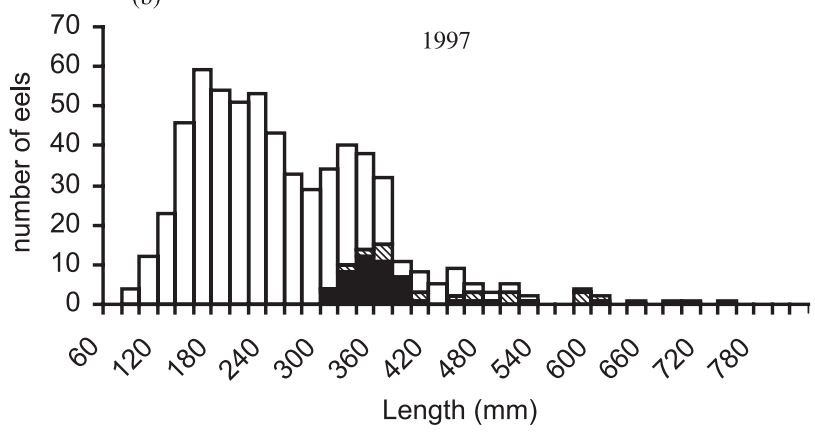

and $89.3 \%$ in 1997 . Silver and yellow/silver eels represented $13.9 \%$ of the sample in 1996 and $11.6 \%$ in 1997 . There seems to be a decrease in the silver eel proportion in the samples during the study period. However, this phenomenon may be biased by the sampling methodology and needs to be verified by other means (see Population size estimates section above).

During the study period, the densities of all stages remained stable (Table 1), with an average of $0.45 \mathrm{eel} \cdot \mathrm{m}^{-2}$. The proportion of silver eels remains stable, with $8.7 \%$ in 1996 and $8.9 \%$ in 1997 . The proportion of yellow/silver eels did not vary significantly either (2.2\% in 1996 and 1997). Therefore, the proportion of potential breeders (silver and yellow/silver eels) amounts to roughly $11 \%$ of the stock in both 1996 and 1997.

The average biomass decreased from $21 \mathrm{~g} \cdot \mathrm{m}^{-2}$ in 1996 to $17 \mathrm{~g} \cdot \mathrm{m}^{-2}$ in 1997 . This decrease was mainly due to yellow eels dropping from $15 \mathrm{~g} \cdot \mathrm{m}^{-2}$ in 1996 to $11 \mathrm{~g} \cdot \mathrm{m}^{-2}$ in 1997. None of these changes were statistically significant (Student $t$ test, $p=0.30)$. Silver eel biomass represented $5 \mathrm{~g} \cdot \mathrm{m}^{-2}$ (23.1\% of the stock) in 1996 and $4 \mathrm{~g} \cdot \mathrm{m}^{-2}(23.5 \%$ of the stock) in 1997, these differences being statistically insignificant (Student's $t$ test, $p=0.31$ ).

In 1996, a total of 59 silver eels, 17 yellow/silver eels, and 328 yellow eels were PIT tagged (Table 2). In 1997, 22 silver eels were caught (eight had already been PIT tagged as yellow or silver eels in 1996 and the remaining 14 were PIT tagged), 14 yellow/silver eels were tagged (one had been tagged the year before), and 106 yellow eels (19.7\%) were tagged (48 had been tagged the year before).

\section{Catadromous migrations}

\section{General characteristics}

A total of 1333 eels $(204 \mathrm{~kg}$ ) were caught in the downstream migration trap (Fig. 3). The number of emigrants was stable during both seasons: $678(85 \mathrm{~kg})$ in 1996 and 655 $(119 \mathrm{~kg})$ in 1997 . The biomass appeared to be $40 \%$ higher in 1997 despite a reduced number of eels, indicating an increase in the sizes in 1997 (see below). A very large majority of individuals were silver eels (99\%), and only about $1 \%$ were yellow/silver eels. During the 1996 season, 2.2\% of the population were yellow/silver eels and none were yellow/silver eels in 1997.

The population structures were very similar in the 1996 and 1997 seasons, with size ranges from 290 to $991 \mathrm{~mm}$. The length-frequency appears to be bimodal (Fig. 3): 300420 and $>420 \mathrm{~mm}$ in both years. The first mode represents $73.4 \%$ of the population in 1997 versus $80.0 \%$ in 1996 . All eels in this size-class are assumed to be males and those $>420 \mathrm{~mm}$ to be females (Tesch 1977; Rossi and Colombo 1979; Adam 1997). Therefore, the emigrating eel population appeared to be dominated by males in the Frémur catchment during the study period.

\section{Migration dynamics}

Downstream migrations occurred during the whole study period (Fig. 4), but $84.9 \%$ of the migration fluxes occurred within 7 weeks. Two peaks were observed: the first lasted 4 weeks starting in February 1997, comprising 88.3\% of "1996 season" migrants, and the second lasted 3 weeks starting in April 1998, representing 81.4\% of "1997 season" migrants. Both migration peaks occurred very late in the season compared with usual migration periods occurring in the region and were triggered mainly by high water discharges.

Most downstream migration only occurred when the Bois Joli reservoir was full, allowing water to flow over the dam (Fig. 4). Acou et al. (2000) showed that once the water flowed over the dam, other environmental factors such as flow, atmospheric pressure, rainfall, and lunar phase (Fig. 5) influenced migration intensity. However, no significant relationship was found between temperature and migration intensity during the peak, which lasted a too short a time for this parameter to play a role (Acou 1999). A general model was developed to predict escapement of silver eels based on population parameters and environmental conditions (Acou 1999; Acou et al. 2000).

\section{Stock - downstream migration relationship}

\section{Stock estimates from electrofishing}

During the study period, electrofishing was used to assess the resident stock of eels, including silver and yellow/silver eels (Table 1). These eels were assumed to be "candidates for emigration" during the next season. According to stock estimates based on electrofishing, a total of 3000 silver eels and 750 yellow/silver eels were expected in the downstream trap during the 1996 and 1997 seasons (Table 1). But in fact, the emigrant silver eel run amounted to 678 silver and 
Table 1. Characteristics of the sedentary fraction of the eel population in 1996 and 1997 estimated by electrofishing.

\begin{tabular}{|c|c|c|c|c|}
\hline & All stages & Silver eels & Yellow eels & Yellow/silver eels \\
\hline \multicolumn{5}{|l|}{$1996(N=30)$} \\
\hline \multicolumn{5}{|c|}{ Density $\left(\right.$ no. $\left.\cdot \mathrm{m}^{-2}\right)$} \\
\hline Mean & 0.46 & 0.04 & 0.41 & 0.01 \\
\hline SD & 0.85 & 0.08 & 0.81 & 0.02 \\
\hline Stock (no.) & 34500 & 3000 & 30700 & 750 \\
\hline \multicolumn{5}{|c|}{ Biomass $\left(\mathrm{g} \cdot \mathrm{m}^{-2}\right)$} \\
\hline Mean & 21 & 5 & 15 & 1 \\
\hline SD & 46 & 9 & 42 & 3 \\
\hline Stock (kg) & 1575 & 375 & 1125 & 75 \\
\hline \multicolumn{5}{|l|}{$1997(N=29)$} \\
\hline \multicolumn{5}{|c|}{ Density $\left(\right.$ no. $\left.\cdot \mathrm{m}^{-2}\right)$} \\
\hline Mean & 0.45 & 0.04 & 0.4 & 0.01 \\
\hline $\mathrm{SD}$ & 0.43 & 0.07 & 0.41 & 0.02 \\
\hline Stock (no.) & 33750 & 3000 & 30000 & 750 \\
\hline \multicolumn{5}{|c|}{ Biomass $\left(\mathrm{g} \cdot \mathrm{m}^{-2}\right)$} \\
\hline Mean & 17 & 4 & 11 & 2 \\
\hline SD & 17 & 8 & 10 & 4 \\
\hline Stock (kg) & 1275 & 300 & 825 & 150 \\
\hline
\end{tabular}

Note: Stock is the estimation of the population size in the whole catchment in numbers and in kilograms (mean $\times$ water surface of the catchement) and $N$ is the number of sampled stations.

Table 2. Number of PIT-tagged and recaptured eels marked in 1996 and 1997 using electrofishing and fyke nets.

\begin{tabular}{|c|c|c|c|c|c|c|c|c|c|c|c|}
\hline \multirow{2}{*}{\multicolumn{3}{|c|}{ Tagging }} & \multicolumn{9}{|c|}{ Recapture } \\
\hline & & & \multicolumn{4}{|c|}{ Silver eels } & \multicolumn{2}{|c|}{ Yellow silver eels } & \multicolumn{2}{|c|}{ Yellow eels } & \multirow[b]{2}{*}{ Total } \\
\hline Eel stage & Electrofishing period & No. & $\begin{array}{l}\text { Trap } \\
1996\end{array}$ & $\begin{array}{l}\text { Trap } \\
1997\end{array}$ & $\begin{array}{l}\text { EF } \\
\text { spring } \\
1997\end{array}$ & $\begin{array}{l}\text { EF } \\
\text { autumn } \\
1997\end{array}$ & $\begin{array}{l}\text { EF } \\
\text { spring } \\
1997\end{array}$ & $\begin{array}{l}\text { EF } \\
\text { autumn } \\
1997\end{array}$ & $\begin{array}{l}\text { EF } \\
\text { spring } \\
1997\end{array}$ & $\begin{array}{l}\text { EF } \\
\text { autumn } \\
1997\end{array}$ & \\
\hline \multirow[t]{3}{*}{ Silver } & Autumn 1996 & 59 & 12 & 5 & & 2 & & & 1 & & 20 \\
\hline & Spring 1997 & & & & & & & & & & 0 \\
\hline & Autumn 1997 & 22 & & 5 & & & & & & & 5 \\
\hline \multirow{3}{*}{ Yellow/silver } & Autumn 1996 & 17 & & & & 1 & & & & 1 & 2 \\
\hline & Spring 1997 & & & & & & & & & & 0 \\
\hline & Autumn 1997 & 14 & & & & & & & & & 0 \\
\hline \multirow[t]{4}{*}{ Yellow } & Autumn 1996 & 328 & 1 & 2 & & 3 & & & 6 & 33 & 45 \\
\hline & Spring 1997 & & & & & 1 & & 1 & & 14 & 16 \\
\hline & Autumn 1997 & 106 & & & & 1 & & & & & 1 \\
\hline & Total & 546 & 13 & 12 & 0 & 8 & 0 & 1 & 7 & 48 & 89 \\
\hline
\end{tabular}

Note: The eels were recaptured either in the catchment (EF) or in the traps (Trap).

yellow/silver eels during the 1996 season and 655 silver eels during the 1997 season.

\section{Comparison of population structures}

Population structures of silver eels sampled in the catchment (electrofishing and fyke nets) were very similar to those of migrant eels captured in the downstream trap (Fig. 3). A very slight difference in the size of males occurred, with those of the catchment being $15 \mathrm{~mm}$ smaller on average than those caught in the trap. Also, females were slightly less represented in the catchment than in the trap. However, none of the observed differences were statistically significant, according to Student's $t$ and KolmogorovSmirnov tests $(p>0.95)$, respectively. Therefore, both approaches gave a very similar representation of silver eels population in the catchment, and since the traps constitute an exhaustive method, we assume that the sampling plan that we used provides for reliable information on silver eel populations at the scale of the river system.

\section{Stock estimates using PIT tags}

Among the 59 silver eels tagged in 1996, 12 in 1996 and five in 1997 were found in the downstream trap (Table 2). In other words, $20.3 \%$ of the candidates for emigration (silver eels) present in the catchment actually emigrated during the following migration season. The stock of silver eels in the total catchment is estimated (Petersen estimate) at 3340 in 1996 and 2885 in 1997 . These results are very similar to those obtained by electrofishing (see Table 1), suggesting that probably both stock assessment methods are efficient. 
Fig. 3. Comparison of silver eel population structure caught in the catchment (river) by electrofishing and fyke nets in (a) September 1996 and (b) September 1997 and the emigrating silver eel population (descending) caught in the downstream trap during the subsequent 1996 season (October 1, 1996, to September 9, 1997) and 1997 season (October 1, 1997, to June 1, 1998). Open bars, silver eels caught in the river (68 and 47 eels in 1996 and 1997, respectively); solid bars, silver eels caught in the downstream trap (678 and 655 in 1996 and 1997, respectively).
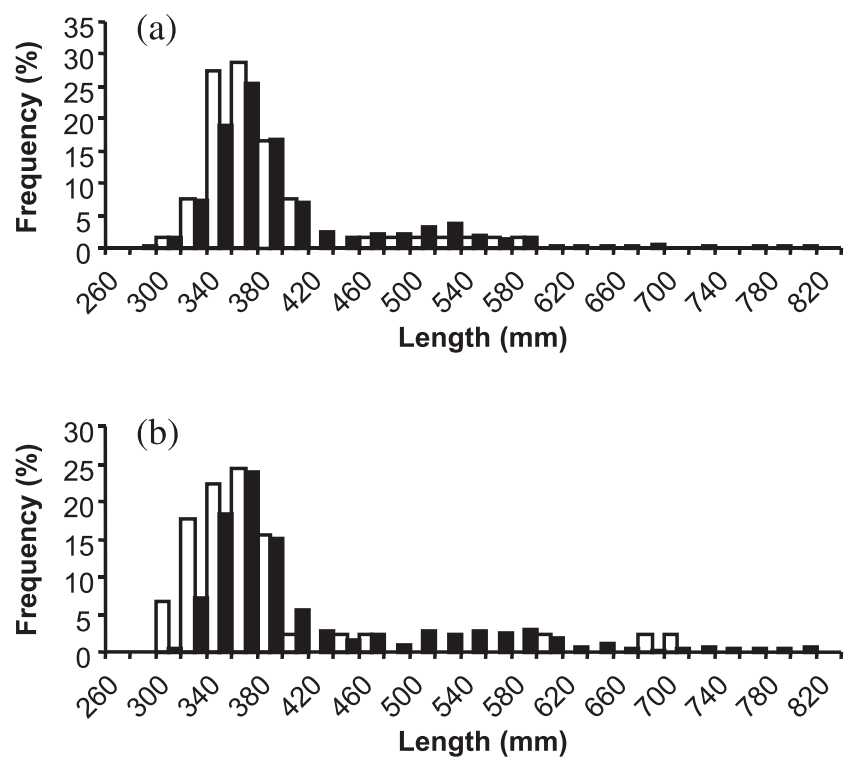

\section{Migrating behaviour and mortality}

Among the 59 silver eels tagged in 1996, 12 (20.3\%) were found in the downstream trap during the 1996 season (Table 2). A total of three were recaptured in the river in 1997; among them, two were still silver eels and one had lost silver eel characteristics. During the 1997 season, five of the eels tagged in 1996 were caught in the downstream trap. Combined with the two caught in the river at silver eel stages, at least seven eels $(11.9 \%)$ remained silver during more than a year and five $(8.5 \%)$ emigrated more than 18 months after metamorphosis into silver eels. This means that 20 eels $(33.9 \%)$ were recaptured, from which 17 $(28.8 \%)$ were recaptured in the downstream trap. At the end of the experiment, the remaining eels were still in the catchment, died, or escaped during floods. Among the 22 silver eels tagged in 1997 , only five $(22.7 \%)$ were recaptured during the following migration season.

Among the 17 yellow/silver eels tagged in 1996, two were recaptured in the catchment during autumn 1997, one as a silver eel and the other as a yellow eel. None of the yellow/ silver eels marked in 1996 and in 1997 were recaptured in the downstream trap the following year. This suggests that they are in a maturing stage (or regression, since one had been found as a yellow/silver eel). Therefore, they do not appear to be real candidates for emigration.

A total of 328 yellow eels were tagged in 1996. One was captured the same year as a silver eel in the downstream trap, suggesting a rapid metamorphosis. Two were caught in the downstream trap during the following season. In the catchment, 42 eels were recaptured, including 39 yellow eels $(93 \%)$ and three silver eels (7\%). In autumn 1997, 106 yellow eels were tagged. One was recaptured a few days later.

\section{Discussion}

The present study permitted the characterisation of the eel stock in the Frémur catchment, showing that silver eels represented almost $10 \%$ of the sedentary population. We assume that this percentage is representative of short and obstructed rivers, but extrapolation to other systems should be considered carefully according to local environmental conditions and population parameters.

The sampling was conducted in September in both years, when most silvering eels have already started or finished their metamorphosis (Tesch 1977; Fontaine 1994). Therefore, it was possible to obtain reliable information on the size (3000 silver eels), length ratio, and sex ratio $(85 \%$ males) of the silver eel population in the whole river system. The silver eel stock present in the river before emigration was estimated at 3340 in 1996 and 2885 in 1997. Results were similar to those obtained by electrofishing (3000 silver eels in both years), suggesting that both methods are reliable.

The characteristics of the resident stock were compared with downstream migration data collected at the trap. The basic question was "is it possible to predict the downstream migration fluxes from quantitative data about the sedentary fraction of an eel population and from environmental parameters?"

Around $20 \%$ of the eels identified as silver eels migrated during the following year, as soon as favourable environmental conditions occurred. The quite stable ratio that was observed in both years is probably due to stable population parameters and to favourable migration conditions that occurred sometime in both years. At least 5\% stayed in the river where they were found the next year during electrofishing and $1.5 \%$ recovered yellow eel characteristics. Recovery of yellow eel characteristics has previously been described (Lee 1979). Almost 9\% of the eels stayed an extra year in the catchment and finally emigrated. Therefore, the fate of the $66 \%$ of the silver eels that were not recaptured is unknown. Several hypotheses can be postulated. Firstly, our sampling effort failed to recapture the marked eels (only $2.5 \%$ of the river length sampled), suggesting that they were still dwelling somewhere in the river; subsequent sampling campaigns should enable us to understand the fate of these eels. Secondly, eels may escape from the downstream trap during the migration peak. Roughly $37 \%$ of escapement occurred when the flow exceeded $1500 \mathrm{~L} \cdot \mathrm{s}^{-1}$; some of the tagged eels may have escaped then, but this only concerns at most $2 \%$ of the silver eels. Thirdly, the silver eel stage was not defined correctly by macroscopic criteria, suggesting that migration behaviour is acquired at the end of the silvering metamorphosis, which itself probably lasts several months. This is confirmed by the fact that none of the yellow/silver eels were found in the downstream traps. It also indicates that a silver eel index is needed to correctly assess the size of the "migration candidate" population. Fourthly, natural mortality might have reduced the tagged population. Usually, high eel mortality is rather low in "natural populations," about 5-10\%·year-1 (e.g., Adam 1997). In 
Fig. 4. Weekly trends of silver eel emigration intensity between October 1996 and June 1998 and corresponding water levels in Bois Joli Lake located $6 \mathrm{~km}$ from the sea. Bars, weekly catch in the trap; lines, water level in the reservoir.

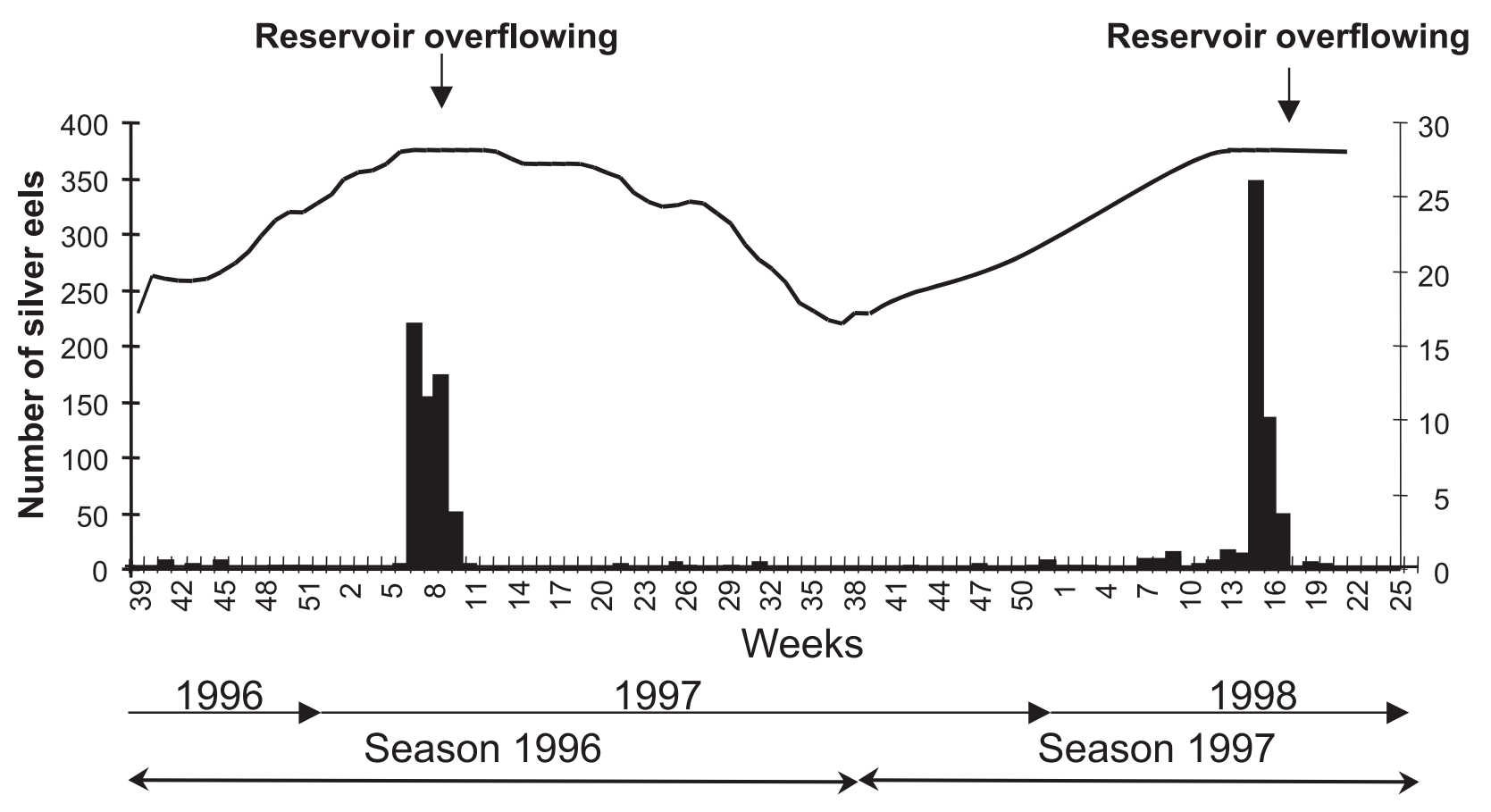

the Frémur, fishing pressure is low (no professional fishery, while anglers mainly focus on cyprinids, esocids, or percids), predation mortality is low because there are few cormorants or herons, and no massive mortality related to eutrophication has been observed (E. Feunteun, unpublished data). Lastly, anthropogenic mortality due to the management of Bois Joli dam has to be considered. Emigration is only possible once the reservoir is full and the water spills over the discharge weirs. The rest of the time, a minimal water flow is controlled by pipes. Emigrant silver eels are probably forced to go through them, but they are killed by pressure at the outlet. A study has just begun to determine this mortality factor. Preliminary results show that about $12 \%$ of the descending silver eels are probably killed because of the pipes (E. Feunteun et al., unpublished data). This is consistent with mortality caused by passage through turbines, which ranges between 5 and $100 \%$ according to Berg (1987) and Langon and Dartidelongue (unpublished). ${ }^{2}$

The current study confirmed the influence of various environmental parameters (river discharge, rainfall, atmospheric pressure, temperature, moon phase, etc.) on the emigration dynamics (e.g., Tesch 1977; Haraldstad et al. 1985; Vollestadt et al. 1986). However, the influence of dam management overruled environmental factors: emigration was impossible until the reservoir was full and water overflowing permitted eels to slide down the 14-m-high weir. The reservoir overflowed quite late in both seasons (February 1997 and April 1998), provoking important delays in the migration peaks compared with nonobstructed rivers (Tesch 1977; Vollestadt et al. 1986). Although silver eels are known to delay emigration by up to a whole year until favourable condi- tions occur (Vollestadt et al. 1994), the consequences of such a delay on breeding success remain unknown. We assume that if the silver eels do not feed during that period, their fat content will obviously diminish, compromising migration and breeding success. The obstructions due to hydraulic works on downstream migration have rarely been looked at, despite the probably important damage that they cause to the eel stocks by reducing breeder escapement from continental waters (Fontenelle et al. 1997). Once the dam was full, downstream migration was triggered by flow increases. After the flow peak, rainfall and (or) low atmospheric pressure may have influenced the migration intensity.

In conclusion, the results of our study were obtained during a period that was too short to provide for a reliable model of the stock-emigration relationships. However, this approach needs to be conducted at least on the mean term to see the effects of unfavourable environmental conditions on migration dynamics. Indeed, during the study period, the conditions permitted emigration, even if a delay in the migration peaks was observed. But how would the silver eel population react to dry weather conditions as observed between 1989 and 1991 ?

The Frémur is very much like a wide range of small catchments of western France, and therefore, the results could eventually be extended to define a regional escapement index without actually measuring escapement everywhere. However, downstream migration dynamics probably vary according to the catchment's size, habitat index, geographic situation, etc., since such parameters are known to influence sex ratio, population structure, and size. Thus, such an approach needs to be conducted at the European and

\footnotetext{
${ }^{2}$ Langon, M., and Dartidelongue, J. 1997. La dévalaison des anguilles (Anguilla anguilla L.) argentées — test de deux dispositifs de dévalaison
} à la centrale hydroélectrique EDF d'Halsou (Nive, Pyrénées Atlantiques), 1996. Revue bibliographique. 
Fig. 5. Emigration intensity and water flow during the migration peak in the 1997 season $(N=599$ silver eels). Bars, daily catches; lines, environmental measures: $(a)$ water flow, $(b)$ rainfall, and $(c)$ atmospheric pressure.

(a)

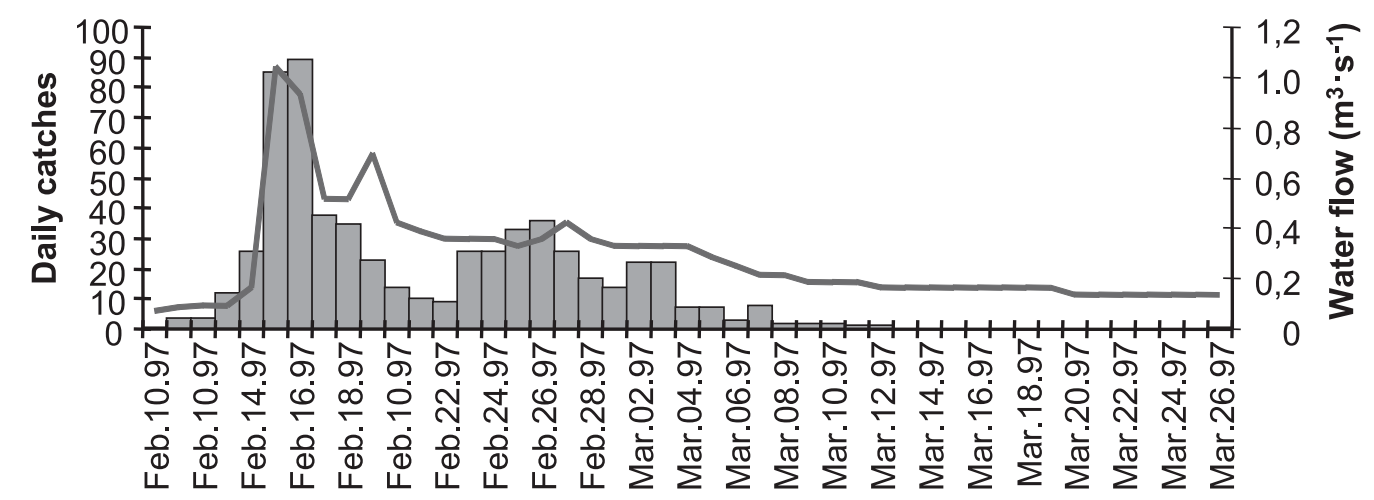

(b)
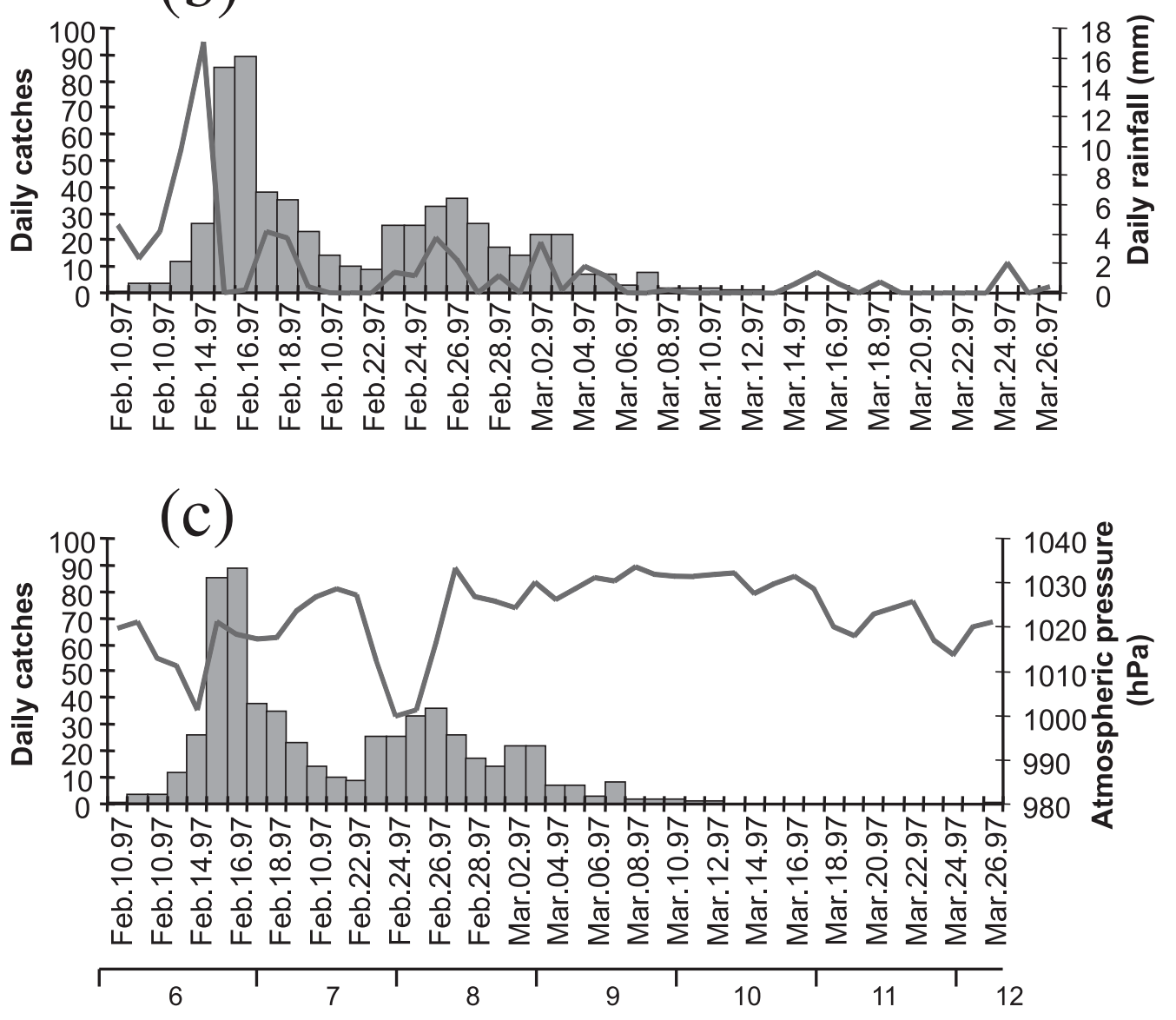

Weeks

North African level to choose a range of representative aquatic continental systems and to define a European silver eel breeder escapement index based on stock characteristics and extrinsic environmental parameters. Such a methodology is required to start reliable monitoring of the species, as recommended by ICES/EIFAC working group on eels (Moriarty and Dekker 1997). This is the first step in defining a stock (breeder escapement) - recruitment (subsequent glass eel immigration) relationship, which is needed to develop a reliable sustainable management policy for the spe- 
cies. Moreover, this kind of approach is important in understanding the implementation of management measures to mitigate impact of dams on silver eel escapement from riverine systems.

\section{Acknowledgements}

This study was funded by the Fédération de Pêche d'Ille et Vilaine, the Contrat de Plan "Poissons Migrateurs," and various regional and local councils. We thank two reviewers, M. Castonguay and W. Dekker, for valuable comments on the manuscript and special thanks to Calou for his help.

\section{References}

Acou, A. 1999. L'anguille européenne, dynamique et déterminisme de la migration catadrome dans un bassin versant anthropisé de Bretagne (Frémur). Diplôme doctoral, l'Université de Rennes I, Rennes, France.

Acou, A., Feunteun, E., Laffaille, P., and Legault, A. 2000. Catadromous migration dynamics of European eel, Anguilla anguilla, in anthropic catchments. Verh. Int. Ver. Limnol. In press.

Adam, G. 1997. L'anguille européenne (Anguilla anguilla L. 1758): dynamique de la sous-population du lac de Grand-Lieu en relation avec les facteurs environnementaux et anthropiques. Thesis, University of Toulouse, Toulouse, France.

Baisez, A. 1997. Outils et méthode d'échantillonnage d'une fraction de la population d'anguille (Anguilla anguilla L. 1758), dans un marais littoral (Domaine de Certes, Bassin d'Arcachon). DESS University of Caen, Caen, France.

Berg, R. 1987. Fishereischäden durch turbinen. Arb. Dtsch. Fisch. Verband., Hamburg. pp. 41-47.

Carle, F.L., and Strub, M.R. 1978. A new method for estimating population size from removal data. Biometrics, 34: 621-630.

Chancerel, F. 1994. La répartition de l'Anguille en France. Bull. Fr. Pêche Piscic. 335: 289-294.

Feunteun, E. 1994. Le peuplement piscicole du marais littoral endigué de Bourgneuf-Machecoul (France, Loire-Atlantique). Approche méthodologique pour une analyse quantitative de la distribution spatiale du peuplement piscicole et de la dynamique de certaines de ses populations. Thesis, University of Rennes, Rennes, France.

Feunteun, E., and Marion, L. 1994. Assessment of grey heron predation on fish communities: the case of the largest European colony. Hydrobiologia, 279/280: 327-344.

Feunteun, E., and Vigneux, E. (Editors). 1998. Numéro spécial anguilles. Bull. Fr. Pêche Piscic. 349: 97-233.

Feunteun, E., Acou, A., Guillouët, J., Laffaille, P., and Legault, A. 1998. Spatial distribution of an eel population (Anguilla anguilla L.) in a small coastal catchment of northern Brittany (France). Consequences of hydraulic works. Bull. Fr. Pêche Piscic. 349: 129-139.

Fontaine, Y.A. 1994. L'argenture de l'anguille: métamorphose, anticipation, adaptation. Bull. Fr. Pêche Piscic. 335: 171-185.
Fontenelle, G., Feunteun, E., and Briand, C. 1997. French report. In Management of European eel fisheries. Edited by C. Moriary and W. Dekker. Ir. Fish. Bull. No. 15. pp. 75-81.

Gascuel, D., and Fontenelle, G. 1994. Approche conceptuelle de la modélisation de la dynamique du stock d'anguille dans un bassin versant: intérêt et adaptation du modèle de rendement par recrue. Bull. Fr. Pêche Piscic. 332: 43-56.

Gascuel, D., Feunteun, E., and Fontenelle, G. 1994. Seasonal dynamics of estuarine migration in glass eels (Anguilla anguilla). Aquat. Living Resour. 8: 123-133.

Haines, G.B., and Modde, T. 1996. Evaluation of marking techniques to estimate population size and first year survival of Colorado squawfish. Am. Fish. Soc. Symp. 16: 905-912.

Haraldstad, O., Vollestadt, L.A., and Jonnson, B. 1985. Descent of European silver eels, Anguilla anguilla L., in a Norwegian watercourse. J. Fish Biol. 26: 37-41.

ICES. 1998. European eel. Extract of report of the Advisory Committee on Fishery Management No. 11. ICES, Copenhagen, Denmark.

Lamarque, P.J., Arignon, J., and Gosset, C. 1978. Comparaison des appareils de pêche à l'électricité EPMC et héron. Bull. Fr. Pêche Piscic. 270: 223-236.

Lambert, P., Feunteun, E., and Rigaud, C. 1994. Eel study in freshwater marshes. First analysis of catch probability observed during electric fishing operations. Bull. Fr. Pêche Piscic. 335: 111-122.

Lee, T.W. 1979. Dynamique des populations d'anguilles Anguilla anguillla (L.) des lagunes du bassin d'Arcachon. Thesis, University of Montpellier, Montpellier, France.

Legault, A. 1994. Étude préliminaire du recrutement fluvial de l'anguille. Bull. Fr. Pêche Piscic. 335: 33-42.

Moriarty, C., and Dekker, W. (Editors). 1997. Management of the European eel. Ir. Fish. Bull. No. 15.

Pankhurst, N.W. 1982. Changes in the skin-scale complex with sexual maturation in the European eel, Anguilla anguilla (L.). J. Fish Biol. 21: 549-561.

Parker, S.J. 1995. Homing ability and home range of yellow phase American eels in a tidally dominated estuary. J. Mar. Biol. Assoc. U.K. 75: 127-140.

Prentice, E.F., Flaggs, T.A., and Cutcheon, M.C. 1990. Electronic tag. Feasibility of using implantable passive integrated transponder (PIT) tags in salmonids. Am. Fish. Soc. Symp. 7: 317-322.

Rossi, R., and Colombo, G. 1979. Some observations on age, sex, growth of silver eels (Anguilla anguilla L.) in north Adriatic lagoons. Rapp. P.-v. Réun. Cons. Int. Explor. Mer, 174: 64-69.

Schmidt, J. 1922. The breeding places of the eel. Philos. Trans. R. Soc. Lond. 211: 179-208.

Tesch, F.W. 1977. The eel. Biology and management of anguillid eels. Chapman and Hall, London, U.K.

Vollestadt, L.A., Jonsson, B., Hvidsten, N.A., Naesje, T.F., Haraldstad, O., and Ruud-Hansen, J. 1986. Environmental factors regulating the seaward migration of European silver eels (Anguilla anguilla). Can. J. Fish. Aquat. Sci. 43: 1909-1916.

Vollestadt, L.A., Jonsson, B., Hvidsten, N.A., and Naesje, T.F. 1994. Experimental test of environmental factors influencing the seaward migration of European eels. J. Fish Biol. 45: 641-651. 